\title{
Association with Genetic Polymorphism of rs117033348 and Allergic Disease in Korean Population
}

\author{
Yoonji Kong ${ }^{1,, *}$, Mingyeong Kim ${ }^{1,, *}$, Hyun-Seok Jin ${ }^{1, * *}$ and Sangjung Park ${ }^{1,2, ;, * *}$ \\ ${ }^{1}$ Department of Biomedical Laboratory Science, College of Life and Health Sciences, \\ Hoseo University, Asan, Chungnam 31499, Korea \\ ${ }^{2}$ The Research Institute for Basic Sciences, Hoseo University, Asan, Chungnam 31499, Korea
}

\begin{abstract}
Allergy is an immune response that appears in certain people, and reactions such as coughing, shortness of breath, and hives occur. The immune system plays an important role in homeostasis and host defense, and allergies cause hypersensitivity reactions when an imbalance of immunity occurs. Mutations in the TLR genes are associated with autoimmune conditions such as allergies and asthma. It has been reported that a locus in the TLR1-TLR6-TLR10 region may be associated with atopic sensitization or allergy. Therefore, the purpose of this study was to select an allergy patient group and a healthy control group to determine how the genetic mutation of TLR 1 affects the onset of disease. This study was conducted in 709 patients and 5,025 control groups out of 10,956 patients with data from KARE and HEXA cohorts. As a result of logistic regression analysis of 6 SNPs selected from the TLR1 gene, only rs117033348 showed a statistically significant correlation $(P=0.002356)$. The influence of rs117033348 was examined using PolyPhen-2, and a significant result was shown. Therefore, it can be predicted that the $\mathrm{G}$ base in rs 117033348 will have an influence on the human body. In addition, Geography of Genetic Variants browser was used to confirm the geographical distribution of allele frequencies for the TLR1 gene. Although it was found that there was a large racial difference in the prevalence of TLR1 SNP, it could be confirmed that the polymorphism of rs117033348 conducted in this study was only specific in East Asia when compared with each race.
\end{abstract}

Key Words: Allergy, rs117033348, SNP, TLRI

알러지(allergy)란 특정 사람에게 나타나는 면역 반응으 로 기침, 호흡곤란, 두드러기 등의 반응이 일어난다. 임상 적으로 이러한 증상이 재발할 수 있으며, 만성화 하는 특 성을 갖는다(Jung et al., 1998). 면역 체계는 항상성과 숙 주 방어에 중요한 기능을 한다. 따라서 알러지, 과민성 또 는 면역과 관련된 면역계의 불균형은 아토피성 질환, 두 드러기, 혈관부종과 같은 질병 및 약물 과민 반응에서 매 우 중요하기 때문에 환자의 삶의 질에 영향을 미칠 수
있으며, 지속적인 관리와 치료가 필요해 전 세계적으로 사회경제적 부담이 증가하고 있다(Simon, 2019; Choi and Kong, 2021). 알러지 질환의 발생률과 유병률은 전 세계적 으로 꾸준히 증가하고 있으며, 10 년이 지날수록 특히 어 린이와 청년층에서 증가하고 있는 것으로 알려져 있다. 하지만 이러한 증가에도 알러지 발병에 대한 의료 기술 은 개선되지 않고 있다(Diwakar et al., 2017). 서구 생활 방 식과 오랫동안 연관되어 왔던 알러지 질환은 아시아와 인

Received: June 25, 2021 / Revised: September 14, 2021 / Accepted: September 16, 2021

*Undergraduate student, ${ }^{* *}$ Professor.

${ }^{\S}$ Yoonji Kong and Mingyeong Kim are equal contributors.

${ }^{\dagger}$ Corresponding author: Sangjung Park. Department of Biomedical Laboratory Science, College of Life and Health Sciences, Hoseo University, 20 Hoseo-ro 79 Beon-gil, Asan-si, Chungcheongnam-do 31499, Korea.

Tel: +82-41-540-9967, Fax:+82-41-540-9997, e-mail: sangjung@hoseo.edu

(OThe Korean Society for Biomedical Laboratory Sciences. All rights reserved.

(C) This is an Open Access article distributed under the terms of the Creative Commons Attribution Non-Commercial License (http://creativecommons.org/licenses/by-nc/3.0/) which permits unrestricted non-commercial use, distribution, and reproduction in any medium, provided the original work is properly cited. 
Table 1. Basic characteristics of the subjects in the Exome Chip

\begin{tabular}{lccc}
\hline \hline \multicolumn{1}{c}{ Characteristics } & Controls & Cases & $P$-value \\
\hline Number of subjects & 5,014 & 709 & - \\
Gender [men (\%) / women (\%)] & $2562(51.1) / 2452(48.9)$ & $245(34.6) / 464(65.4)$ & $<0.05$ \\
Age (M years \pm SD) & $50.81 \pm 8.55$ & $51.25 \pm 8.09$ & $<0.05$ \\
\hline
\end{tabular}

Abbreviations: Exome Chip; M, mean value; SD, standard deviation

도에서 유병률이 높아지고 있으며, 한국 역시 지난 20년 동안 눈에 띄게 증가하였다(Simon, 2019; Park et al., 2009). 알러지 질환은 영유아에서 위장관, 청소년은 호흡기, 성 인에서는 심혈관과 저혈압 증상이 나타난다. 이처럼 나이 에 따라 증상의 양상이 변화하는 결과가 보고되었다(Goh et al., 2018). 또한 알러지 반응이 심할 경우 아나필락시스 가 발생할 수 있고, 발병이 빠르며 소량의 항원에 의해 유발될 수 있어 생명을 위협하는 호흡 및 순환 문제를 특징으로 하는 중증의 전신성 과민 반응으로 나타날 수 있다(Reber et al., 2017). 알러지는 유전 가능성이 높아 알러 지 질환의 유전적 기초를 밝히기 위한 많은 노력이 있었 다(Bønnelykke et al., 2015; Potaczek et al., 2017). 하지만 질 병에 대한 지식과 더 나은 이해가 요구되며, 알러지 질환 의 최적화된 예방이 필요하다(Charfi et al., 2010).

Toll-like-receptor (TLR)은 침입하는 병원체를 인식하고 선천 면역을 활성화하는데 중요한 역할을 하는 막 관 통 수용체이다(Gao et al., 2016). 알러지 질환의 발병 기 전에서 TLR 수용체의 역할은 면역 반응의 활성화 및 조 절에 작용하는 생물학적 기능에 기인한다(Dębińska and Boznański, 2014). 면역계 세포는 특정 병원체 관련 분자 패턴(Pathogen Associated Molecular Pattern, PAMP)을 인식 하여 위험을 감지하고, 특정 면역 반응을 일으키는 다양 한 패턴 인식 수용체(Pattern Recognition Receptor, PRR)를 발현한다. TLR 또한 다양한 면역 세포에 의해 발현되는 PRR 중 하나이다(Vijay, 2018). 지질 다당류(LPS), 지단백 질, 편모 및 박테리아 $\mathrm{DNA}$ 를 포함한 광범위한 미생물 산물의 인식을 매개하고, TLR을 통한 신호 전달은 염증 매개체의 생성으로 이어진다(Jang et al., 2017). 미생물에 의한 TLR 자극은 항원제시세포를 활성화하며, 조절 $\mathrm{T}$ 세 포(Treg) 기능에 영향을 미쳐 Th1/Th2 균형 및 Th17 세포 분화를 결정하고, 비만 세포에서 사이토카인 생산 및 호 산구 활성화를 제어한다(Dębińska and Boznański, 2014). 하 지만 TLR 신호 전달 경로의 조절 장애는 알러지 및 천식, 만성 비부비동염, 염증성 장 질환, 죽상 동맥 경화증과 같
이 여러 자가 면역 또는 염증성 질환의 병인에 관여한다 고 알려져 있다(Patra et al., 2020). 또한 게놈 전체 연구의 메타 분석(Genome Wide Meta Analysis)에 의하면 TLR1TLR6-TLR10 영역의 유전자좌는 아토피 감작 또는 알러 지와 연관될 수 있다고 보고되었다(Renkonen et al., 2015). 따라서 $T L R$ 유전자의 변이는 알러지 및 천식과 같은 자 가면역 질환과 관련이 있음을 보여준다(Koponen et al., 2014). 본 연구는 한국인 유전체 역학 조사 사업 코호트 자료를 활용하여 알러지 환자군과 건강 대조군을 선별해 $T L R 1$ 의 유전적 변이가 질병 발병에 어떠한 영향을 주는 지 확인하고자 하였다.

연구 대상자는 한국인 유전체 역학 조사 사업(Korean Genome and Epidemiology Study; KoGES)의 일환인 KARE (Korean Association Resource)와 HEXA (The Health Examinees) 코호트 자료를 분양받아 활용하였다(KBN-2017046) (Cho et al., 2009; Health Examinees Study Group, 2015). 40세 이상의 남녀를 포함한 총 10,956명(KARE: 7,524명, HEXA: 3,432명) 중 알러지 질환으로 진단받은 709 명을 환자군으로 선별하였다. 그리고 천식, 고혈압, 당뇨, 심근 경색, 뇌졸중, 갑상선 질환, 고지혈증, 만성폐쇄성 폐 질환 과 통풍에 대한 과거력이 없는 5,014명을 건강 대조군으 로 선별하였다. 알러지 환자군과 건강 대조군의 임상적 특성을 Table 1에 나타냈다. 이번 연구에 활용한 유전정보 는 질병관리청(KDCA)과 호서대학교에서 연구 윤리 승인 (104131-170822-BR-062-01)을 받아 수행하였다. 총 10,956명 의 유전형 분석은 Exome 영역의 분석을 위해 Illumina HumanExome Chip v1.1 (Illumina, Inc., San Diego, CA, USA) exome chip을 사용하여 분석되었다. 품질 관리 $(\mathrm{QC})$ 과정 에서 DNA 시료는 연구 참여자의 말초 혈액에서 분리 추 출하였고, 유전형 판독 정확도가 $96 \%$ 이하이거나, 과도한 heterozygosity를 가지거나, 성별 불일치가 존재하는 대상 자들은 제외되었다. 본 연구에서는 총 77,311개의 SNP을 대상으로 marker QC를 수행하여 MAF가 $1 \%$ 미만인 SNP 과 전체 분석 대상자 중 $1 \%$ 이상의 결과가 누락된 $\mathrm{SNP}$ 
Table 2. Result of the case-control association analysis between SNP in the TLR1 genes and allergy in the Exome Chip subjects

\begin{tabular}{|c|c|c|c|c|c|c|c|c|c|}
\hline \multirow{2}{*}{ GENE } & \multirow{2}{*}{ CHR } & \multirow{2}{*}{ SNP } & \multirow{2}{*}{$\begin{array}{l}\text { Minor } \\
\text { allele }\end{array}$} & \multirow{2}{*}{$\mathrm{BP}$} & \multicolumn{2}{|c|}{ MAF (n) } & \multirow{2}{*}{$\begin{array}{l}\text { Genetic } \\
\text { Model }\end{array}$} & \multirow{2}{*}{ OR $(95 \% \mathrm{CI})$} & \multirow{2}{*}{$P$-value } \\
\hline & & & & & Controls & Cases & & & \\
\hline \multirow{2}{*}{ TLRI } & \multirow{2}{*}{$4 p 14$} & \multirow{2}{*}{ rs117033348 } & \multirow{2}{*}{ G } & \multirow{2}{*}{38800022} & \multirow{2}{*}{$\begin{array}{l}0.062 \\
(617)\end{array}$} & \multirow{2}{*}{$\begin{array}{l}0.082 \\
(116)\end{array}$} & ADD & $1.385(1.122 \sim 1.708)$ & $2.38 \times 10^{-3}$ \\
\hline & & & & & & & DOM & $1.398(1.121 \sim 1.744)$ & $2.92 \times 10^{-3}$ \\
\hline
\end{tabular}

$P$-value $<0.05$ is indicated in bold; CHR, chromosome; SNP, single nucleotide polymorphism; BP, base pair; MAF, minor allele frequency; $\mathrm{n}$, number of minor; OR, odds ratio; CI, confidence interval. The SNP position are based on the UCSC build 37

을 제외한 후 총 31,506 개의 $\mathrm{SNP}$ 을 분석에 사용하였다 (Marees et al., 2018). 염색체 상의 위치는 UCSC (University of Colombo school of computing) Genome browser on human Feb, 2009 (Genome Reference Consortium Human Build 37)를 기준으로 하였다. 대부분의 통계 분석에는 PLINK version 1.90 beta (http://pngu.mgh.harvard.edu/ purcell/plink)와 PASW Statistics version 21.0 (SPSS Inc. Chicago, IL, USA)을 사용하 였다. 알러지 환자군과 건강 대조군에 대한 유전 변이의 상관 분석은 로지스틱 회귀 분석을 사용하여 GWAS를 시 행하였다. 회귀 분석의 시행에 있어서 나이와 성별을 공 변수로 조정하여 분석하였고, 분석 값에 대한 유의성의 기준은 0.05 미만을 기준으로 하였다.

GWAS 분석 결과, 알러지 질환과 bonferroni correction $\left(6.46 \times 10^{-7}\right)$ 의 결과를 보인 $\mathrm{SNP}$ 는 존재하지 않았다. 따라 서 해당 결과를 각 유전자 레벨로 개별 분석을 수행하였 고 알러지와 연관된 1,621 개의 $\mathrm{SNP}$ 을 확인하였다. 그 중 상대적 위험도(Odds ratio, $\mathrm{OR})$ 가 1.3 이상이면서 $P$-value 가 $10^{-3}$ 이하에 속하는 230 개의 $\mathrm{SNP}$ 을 산출하였고, 알러 지 발병에 높은 감수성을 보이며 $\mathrm{GGV}$ 결과를 통해 동아 시아에서 특이적으로 발현하는 $\mathrm{SNP}$ 을 가진 TLR1 유전자 를 선정하였다. 이를 바탕으로 TLR1 유전자를 대상으로 로지스틱 회귀 분석을 시행하였다. 그 결과 하나의 SNP 이 도출되었고, 통계적으로 유의한 상관관계임을 확인할 수 있었다(Table 2). Additive Model에서의 OR 값은 1.385, 신뢰구간(95\% CI)은 1.122 1.708이며, Dominant Model에 서의 $\mathrm{OR}$ 값은 1.398 , 신뢰구간은 1.121 1.744이다. 또한 Minor Allele Frequency (MAF)는 건강 대조군에서 6.2\%의 빈도를 나타내며, 알러지 환자군에서는 $8.2 \%$ 로 $2 \%$ 의 빈 도 차가 있다. 따라서 Minor allele인 $\mathrm{G}$ 염기를 보유할 경 우 알러지 발병을 증가시키는 방향으로 상관성이 있다는 것을 확인할 수 있었다.

PolyPhen-2를 활용하여 알러지에서 통계적인 유의성을 보인 rs117033348이 가지는 영향력을 알아보았다(Fig. 1). PolyPhen-2는 아미노산의 치환이 단백질의 구조와 기능의

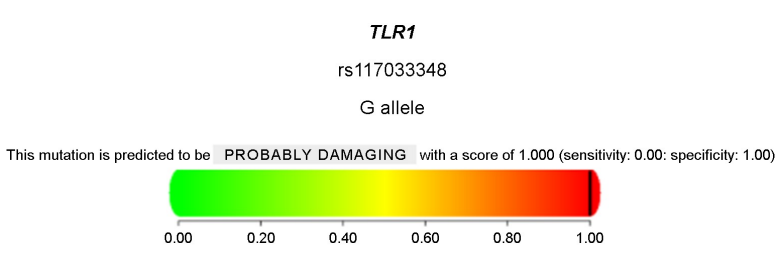

Fig. 1. Confirmation of the probably damaging score of rs117033348 of the TLR1 gene using PolyPhen-2. The rs117033348 showing the highest score for predicted score is marked by black line. This report is HumDiv. The HumDiv model is preferres model for evaluating rare alleles, dense mapping of regions identifies by genome-wide association studies, ans analysis of natural selection. http://genetics.bwh.harvard.edu/cgi-bin/pph2/dbsearch.cgi?dbid= 77810520

차이로 인해 인간에게 미치는 영향력을 Probably Damaging Score로 예측할 수 있다. Score는 0에서 1까지 BENIGN, PROBABLY DAMAGING, POSSIBLY DAMAGING 총 3 가 지로 표현되며, 1 에 가까워질수록 큰 영향을 미칠 것으로 예상할 수 있다. rs117033348의 결과는 아미노산의 변화로 인해 큰 영향을 줄 수 있는 1로 나타났다. 또한 세계적으 로 분포하고 있는 각 인종의 rs117033348의 G 염기 빈도 를 Geography of Genetic Variants (GGV) browser을 이용하여 알아보았다(Fig. 2). GGV는 1000 genome project의 데이터베 이스를 기반으로 특정 인종들의 염기 빈도를 보여준다. 이전 연구에서 TLR1 SNP의 유병률은 인종적으로 큰 차이 가 있다고 보고되었다(Yang and Chiang, 2017). 본 연구에서 진행한 rs117033348의 다형성 역시 각각의 인종과 비교하 였을 때 동아시아 지역에서만 특이적으로 나타나고 있음 을 확인할 수 있었다.

$T L R 1$ 은 세균성 지질 단백질 및 지질 펩티드를 인식하 기 위해 TLR2와 이종이량체를 형성하는 것으로 알려져 있다(Jin et al., 2007). TLR2-TLR1 이종이량체는 그람음성 세균 및 미코플라스마에서 Triacylated Lipopeptides를 인식 한다(Kawai and Akira, 2010). 또한 Pam3CSK4는 TLR1에 의해 매개되는 합성 TLR 리간드로, 세포질 도메인을 통해 $T L R 2$ 와 협력하여 신호 전달 Cascade를 유도해 NF- $\mathrm{KB}$ 신 
rs117033348

chr4:38800022 G/A.

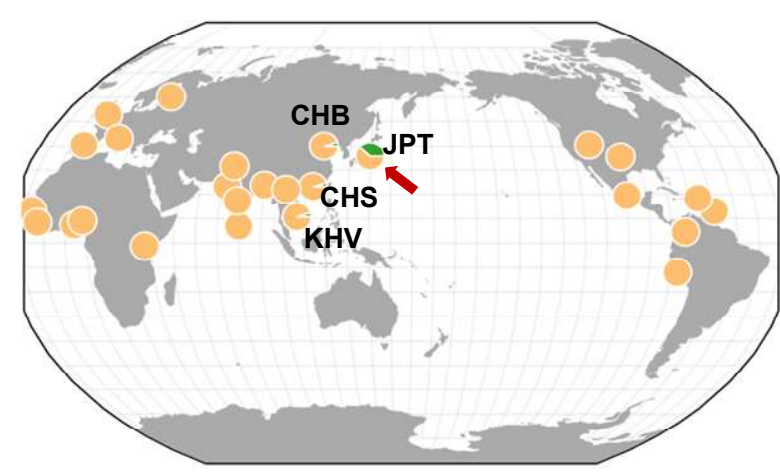

Fig. 2. Confirmation of rs117033348 minor allele frequency of TLRI through Geography of Genetic Variants browser (GGV). The 1000 Genomes project consortium data is used to represent the allele frequencies of ethnic group. $\mathrm{G}$ allele is marked in green and is rarely found in other groups but concentrated in East Asia. MAF of CHB (Han Chinese in Beijing, China), CHS (Han Chinese South, China), and KHV (Kinh in Ho Chi Minh City, Vietnam) populations were less than 0.01 . The red arrow indicates the JPT (Japanese in Tokyo, Japan) population, and the MAF is 0.038 which indicated in green inside the circle.

호 전달 경로를 활성화한다(West et al., 2011). NF-kB의 활 성화는 염증 과정의 시작에 관여하는 사이토카인과 케모 카인을 암호화하는 유전자의 전사를 유도한다(Kwok et al., 2012). 하지만 TLRI의 유전적 변이는 이러한 NF-kB 경로의 활성화를 크게 감소시키며, 면역 반응에 해로운 영향을 미칠 가능성이 높아 염증에 대한 감수성에 기여 할 수 있음을 시사한다(Ben-Ali et al., 2011).

따라서 이번 연구는 TLRI 유전자의 SNP에서 동아시아 인이 Minor allele인 G 염기를 가졌을 경우 알러지에 대한 감수성이 증가하고 있음을 보여주었다. 다만 본 연구에 서는 Exomchip을 이용한 분석 결과를 활용하여 marker $\mathrm{QC}$ 에서 $\mathrm{MAF}$ 가 매우 낮은 marker들이 제외되어 실제 $T L R 1$ 유전자에서는 1 개의 $\mathrm{SNP}$ 만을 확인할 수 있었다. 추후 다른 코호트에서 동일한 유전체 영역에 대한 추가 연구가 필요할 것으로 보인다. 지난 수십 년 동안 천식, 피부염 및 비염과 같은 알러지와 아토피 장애의 증가가 관찰되었지만 이러한 기전은 아직 명확하지 않아 새로운 치료법의 개발이 제한적이다(Verschoor and von Gunten, 2019). 하지만 현재까지 알러지의 발생과 환경 및 유전적 요인과의 상관관계에 대한 연구들이 많이 진행되고 있으 며, 본 연구는 TLRI의 유전적 다형성이 알러지 발병에 영향을 미칠 수 있음을 제시하고 있다. 이것은 또한 알러
지 발병의 이해에 도움을 줄 수 있을 것으로 기대된다.

\section{ACKNOWLEDGEMENT}

Following are results of a study on the "Leaders in INdustryuniversity Cooperation +" Project, supported by the Ministry of Education and National Research Foundation of Korea

\section{CONFLICT OF INTEREST}

The authors have no conflicts of interest to disclose.

\section{REFERENCES}

Ben-Ali M, Corre B, Manry J, et al. Functional characterization of naturally occurring genetic variants in the human TLR1-2-6 gene family. Hum Mutat. 2011. 32: 643-652.

Bønnelykke K, Sparks R, Waage J, Milner JD. Genetics of allergy and allergic sensitization: common variants, rare mutations. Curr Opin Immunol. 2015. 36: 115-126.

Charfi A, Zainine R, Ben Ali S, et al. Rhinites allergiques [Allergic rhinitis]. Tunis Med. 2010. 88: 690-695.

Cho YS, Go MJ, Kim YJ, et al. A large-scale genome-wide association study of Asian populations uncovers genetic factors influencing eight quantitative traits. Nat Genet. 2009. 41: 527534.

Choi HG Kong IG Asthma, Allergic Rhinitis, and Atopic Dermatitis Incidence in Korean Adolescents before and after COVID-19. J Clin Med. 2021. 10: 3446.

Dębińska A, Boznański A. The role of Toll-like receptors in the pathogenesis of allergic diseases - where is the truth? Postepy Hig Med Dosw (Online). 2014. 7; 68: 230-237.

Diwakar L, Cummins C, Lilford R, Roberts T. Systematic review of pathways for the delivery of allergy services. BMJ Open. 2017. 7: e012647.

Gao J, Wei L, Wei J, et al. TLR1 polymorphism rs4833095 as a risk factor for IgA nephropathy in a Chinese Han population: A case-control study. Oncotarget. 2016. 7: 83031-83039.

Goh SH, Soh JY, Loh W, et al. Cause and Clinical Presentation of Anaphylaxis in Singapore: From Infancy to Old Age. Int Arch Allergy Immunol. 2018. 175: 91-98.

Health Examinees Study Group. The Health Examinees (HEXA) study: rationale, study design and baseline characteristics. Asian Pac J Cancer Prev. 2015. 16: 1591-1597.

Jang YH, Choi JK, Jin M, et al. House Dust Mite Increases proTh2 Cytokines IL-25 and IL-33 via the Activation of TLR1/6 
Signaling. J Invest Dermatol. 2017. 137: 2354-2361.

Jin MS, Kim SE, Heo JY, et al. Crystal structure of the TLR1TLR2 heterodimer induced by binding of a tri-acylated lipopeptide. Cell. 2007. 130: 1071-1082.

Jung AN, Lee SR, Kim SY, Kang HJ, Lee KH, Cho YS. Analysis of MAST test result for 1 year. Korean J Clin Lab Sci. 1998. 30. 162-168.

Kawai T, Akira $\mathrm{S}$. The role of pattern-recognition receptors in innate immunity: update on Toll-like receptors. Nat Immunol. 2010. 11:373-384.

Koponen P, Vuononvirta J, Nuolivirta K, Helminen M, He Q, Korppi $\mathrm{M}$. The association of genetic variants in toll-like receptor 2 subfamily with allergy and asthma after hospitalization for bronchiolitis in infancy. Pediatr Infect Dis J. 2014. 33: 463466.

Kwok YH, Hutchinson MR, Gentgall MG, Rolan PE. Increased responsiveness of peripheral blood mononuclear cells to in vitro TLR 2, 4 and 7 ligand stimulation in chronic pain patients. PLoS One. 2012. 7: e44232.

Marees AT, de Kluiver H, Stringer S, et al. A tutorial on conducting genome-wide association studies: Quality control and statistical analysis. Int J Methods Psychiatr Res. 2018. 27: e1608.

Patra MC, Achek A, Kim GY, et al. A Novel Small-Molecule Inhibitor of Endosomal TLRs Reduces Inflammation and Alleviates Autoimmune Disease Symptoms in Murine Models. Cells. 2020. 9: 1648.

Park HS, Choi GS, Cho JS, Kim YY. Epidemiology and current status of allergic rhinitis, asthma, and associated allergic diseases in Korea: ARIA Asia-Pacific workshop report. Asian Pac J Allergy Immunol. 2009. 27: 167-171.
Potaczek DP, Harb H, Michel S, et al. Epigenetics and allergy: from basic mechanisms to clinical applications. Epigenomics. 2017. 9: 539-571.

Reber LL, Hernandez JD, Galli SJ. The pathophysiology of anaphylaxis. J Allergy Clin Immunol. 2017. 140: 335-348.

Renkonen J, Toppila-Salmi S, Joenväärä $\mathrm{S}$, et al. Expression of Toll-like receptors in nasal epithelium in allergic rhinitis. APMIS. 2015. 123: 716-725.

Simon D. Recent Advances in Clinical Allergy and Immunology 2019. Int Arch Allergy Immunol. 2019. 180: 291-305.

Verschoor D, von Gunten S. Allergy and Atopic Diseases: An Update on Experimental Evidence. Int Arch Allergy Immunol. 2019. 180: 235-243.

Vijay K. Toll-like receptors in immunity and inflammatory diseases: Past, present, and future. Int Immunopharmacol. 2018. 59: 391-412.

West AP, Brodsky IE, Rahner C, et al. TLR signalling augments macrophage bactericidal activity through mitochondrial ROS. Nature. 2011. 472: 476-480.

Yang CA, Chiang BL. Toll-like receptor 1 N248S polymorphism affects $\mathrm{T}$ helper 1 cytokine production and is associated with serum immunoglobulin E levels in Taiwanese allergic patients. J Microbiol Immunol Infect. 2017. 50: 112-117.

https://doi.org/10.15616/BSL.2021.27.3.177

Cite this article as: Kong Y, Kim M, Jin HS, Park S. Association with Genetic Polymorphism of rs117033348 and Allergic Disease in Korean Population. Biomedical Science Letters. 2021. 27: 177-181. 